\title{
Yield and technological quality of sugarcane cultivars under infestation of Diatraea saccharalis (Fabr., 1794)
}

\author{
Produtividade e qualidade tecnológica de cultivares de cana-de-açúcar sob \\ infestação de Diatraea saccharalis (Fabr., 1794)
}

\author{
Carlos Alberto da Silva Ferreira', Marcus Vinícius Santana1* (D), Jardel Barbosa dos Santos², \\ Tássia Tuane Moreira dos Santos' ${ }^{1}$, Lucas Morais Lôbo', Paulo Marçal Fernandes'
}

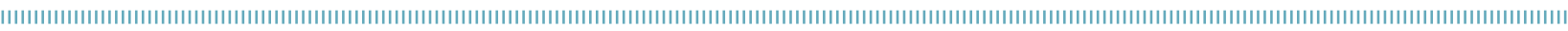

\begin{abstract}
The sugarcane borer, Diatraea saccharalis (Fabr., 1794) (Lepidoptera: Crambidae), is one of the main pests of sugarcane. This pest can reduce the quality and yield of the crop. Information on the quality and yield of cultivars in relation to the attack of sugarcane borer are necessary, since they guide the choice of the best materials for use in joint with other management tactics. Two field experiments were conducted in 2011 and 2012 to compare the quality and yield of 16 commercial sugarcane cultivars (IACSP93-3046, IACSP94-2094, IACSP94-2101, IAC91-1099, IACSP95-5000, IAC87-3396, RB92579, RB867515, RB966928, CTC2, CTC4, CTC9, CTC11, CTC15, CTC18 and SP86-0042) relative to the natural infestation of $D$. saccharalis. The experimental design was a randomized complete block with four replications. There was no difference between treatments for infestation index, with averages of 1.2 to $8.7 \%$ of bored internodes. Higher percentages of internodes with red rot were observed for CTC9, CTC2 and RB966928. The cultivars CTC4 and RB92579 infested with $D$. saccharalis resulted in lower technological quality, due the reduction in the contents of brix, apparent sucrose content (POL) and purity; and increase of the reducing sugars and, consequently, lower theoretically recoverable sugar (TRS). On the other hand, the lowest yields ( $\mathrm{t}$ of cane $\mathrm{ha}^{-1}$ ) were observed for CTC18, IACSP94-2094, IACSP94-2101 and RB966928. Therefore, according to the hierarchical cluster analysis (UPGMA), the cultivars RB867515, CTC11, IAC91-1099, CTC15, SP86-0042, CTC2 and IACSP94-3046 were resistant to D. saccharalis.
\end{abstract}

KEYWORDS: cluster analysis; damage; resistance; Saccharum officinarum L.
RESUMO: A broca-da-cana, Diatraea saccharalis (Fabr., 1794) (Lepidoptera: Crambidae), é uma das principais pragas da cana-de-açúcar. Essa praga pode reduzir a qualidade e a produtividade da cultura. Informaçôes sobre a qualidade e a produtividade de cultivares em relação ao ataque da broca-da-cana são necessárias, pois orientam a escolha dos melhores materiais para utilização em conjunto com outras táticas de manejo. Dois experimentos de campo foram instalados em 2011 e 2012 para comparar a qualidade e a produtividade de 16 cultivares comerciais de cana-de-açúcar (IACSP93-3046, IACSP94-2094, IACSP94-2101, IAC91-1099, IACSP95-5000, IAC87-3396, RB92579, RB867515, RB966928, CTC2, CTC4, CTC9, CTC11, CTC15, CTC18 e SP86-0042) em relação à infestação natural de $D$. saccharalis. O delineamento dos experimentos foi em blocos completos ao acaso, com quatro repetiçóes. Não houve diferença entre os tratamentos para a intensidade de infestação, com médias de 1,2 a $8,7 \%$ de entrenós brocados. Maiores porcentagens de entrenós com podridão-vermelha foram observadas para CTC9, CTC2 e RB966928. Os cultivares CTC4 e RB92579 infestados com $D$. saccharalis resultaram em menor qualidade tecnológica, por causa da redução nos teores de brix, teor de sacarose aparente (POL) e pureza; e aumento dos açúcares redutores e, consequentemente, menor quantidade de açúcar teoricamente recuperável (ATR). Por outro lado, as menores produtividades ( $\mathrm{t}$ de cana $\mathrm{ha}^{-1}$ ) foram observadas para CTC18, IACSP94-2094, IACSP94-2101 e RB966928. Portanto, de acordo com a análise hierárquica de agrupamento (UPGMA), os cultivares RB867515, CTC11, IAC91-1099, CTC15, SP86-0042, CTC2 e IACSP94-3046 mostraram-se resistentes a D. saccharalis.

PALAVRAS-CHAVE: análise de agrupamento; danos; resistência; Saccharum officinarum L.

'Universidade Federal de Goiás - Goiânia (GO), Brazil

${ }^{2}$ Instituto Federal de Educação, Ciência e Tecnologia do Tocantins, Campus Avançado da Lagoa da Confusão - Lagoa da Confusão (TO), Brazil

*Corresponding author: mvsantana@outlook.com

Received on: 01/15/2017. Accepted on: 03/21/2018

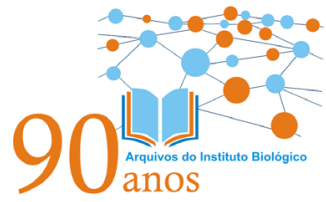




\section{INTRODUCTION}

The worldwide market of sugarcane moves, per year, approximately 1.9 billion ton of this product. Brazil is an important country in world scenario of sugarcane, being the greatest producer, followed by India and China (FAO, 2013). At 2015/2016 harvest, with important featured in national economy, Brazil produced 665.6 million ton of sugarcane in 8 million hectares, resulting in an average yield about $76.903 \mathrm{~kg} \mathrm{ha}^{-1}$ (CONAB, 2016). However, the sugarcane borer Diatraea saccharalis (Fabr., 1794) (Lepidoptera: Crambidae) may significantly reduce the yield and the quality of sugarcane (DINARDO-MIRANDA et al., 2012a, 2013).

Damages caused by sugarcane borer can occur during all phases of the plant development. The larvae are able to penetrate plant tissues of any age, creating galleries within the stems as result of their feeding. These holes also serve as entrance to secondary phytopathogenic fungi (Colletotrichum falcatum, Fusarium moniliforme and F. subglutinans), causers of red rot (SATHYABHAMA et al., 2016; VISWANATHAN et al., 2009). The injury instigated by the insects combined with the phytopathogenic microorganisms may cause even greater losses of yield. The pest attack decreases the sugar content (by inversion of the sucrose stored in the plant) and contaminates the broth, which hinders the fermentation (DINARDO-MIRANDA, 2008; DINARDO-MIRANDA et al., 2012b). Therefore, the sugarcane borer infestations can interfere with the quality of the raw material (sucrose content, soluble solids, purity, acidity of juice and fiber) and reduce the sugar production and quality.

Studies conducted by Copersucar in 1990 showed that each $1 \%$ of infestation index (II) of borer sugarcane caused losses of $1.50 \%$ in stem productivity, $0.49 \%$ in sugar productivity and $0.28 \%$ in alcohol productivity (ARRIGONI, 2002; DINARDO-MIRANDA et al., 2011), revealing the importance of the pest in this culture. However, the cultivars can response of different forms to the insect attacks, e.g., greater attacks of sugarcane borer resulted in an increase in the fiber content and in reducing sugar; and decrease in apparent sucrose content (POL) of sugarcane and in purity of sugarcane cultivars IAC91-1099, IACSP93-3046 and IACSP95-5000 (DINARDO-MIRANDA et al., 2012b). When the sugarcane-plant was infested and damaged by the sugarcane borer, the cultivars IACSP94-4004, IACSP96-2042 and SP91-1115 resulted in greater fiber contents. While in ratoon, the infested plots produced $10 \%$ less, with lower purity contents and greater total reducing sugar contents when compared with the non-infested plots (DINARDO-MIRANDA et al., 2013).

Information about the cultivars behaviour in relation to the sugarcane borer attacks are necessary, since they guide the choice of the best material to be used in combination with other management tactics to control this insect. Besides, the use of resistant cultivars is a helpful tool in the integrated pest management (LARA, 1991). Thus, this study aimed to evaluate the effect of natural infestation of $D$. saccharalis on the yield and technological quality of 16 sugarcane cultivars.

\section{MATERIAL AND METHODS}

The study was conducted at Jalles Machado S/A power plant, in Goianésia, Goiás (1517’43” S, 4856'13” W, 600-m altitude). Two experiments were performed: the first one, from April 2011 to May 2012; and the second one, from August 2011 to September 2012, during the cane-plant cycle. The soil was classified as dystrophic Yellow Red Latosol (Oxisol), according to Brazilian system soil classification (SANTOS et al., 2013). According to Köppen classification, the climate type is Aw, which characterizes this region as tropical with dry season in winter (ALVARES et al., 2013). The average annual precipitation stipulated for the Goiás state is approximately $1,500 \mathrm{~mm}$, while the average temperature is $23.4^{\circ} \mathrm{C}$. The data of precipitation and temperature during the experiments were obtained of a weather station from the Instituto Nacional de Meteorologia (INMET — http://www.inmet.gov.br/portal/index.php? $r=h o m e /$ page\&page=sobre_inmet), in Brazil, located $12 \mathrm{~km}$ from the experiments (Fig. 1).

Sixteen commercial sugarcane cultivars (IACSP93-3046, IACSP94-2094, IACSP94-2101, IAC91-1099, IACSP95-5000, IAC87-3396, RB92579, RB867515, RB966928, CTC2, CTC4, СТC9, СТC11, СТC15, СTC18 and SP86-0042) were used. The experimental design was a randomized complete block with four replications. Each experimental unit consisted of four lines of $15 \mathrm{~m}$ long, with spacing between lines of $1.5 \mathrm{~m}$, totaling $90 \mathrm{~m}^{2}$ of total area.

On March 2011, before the installation of the experiments, soil fertility was accessed. The soil samples were composed of six

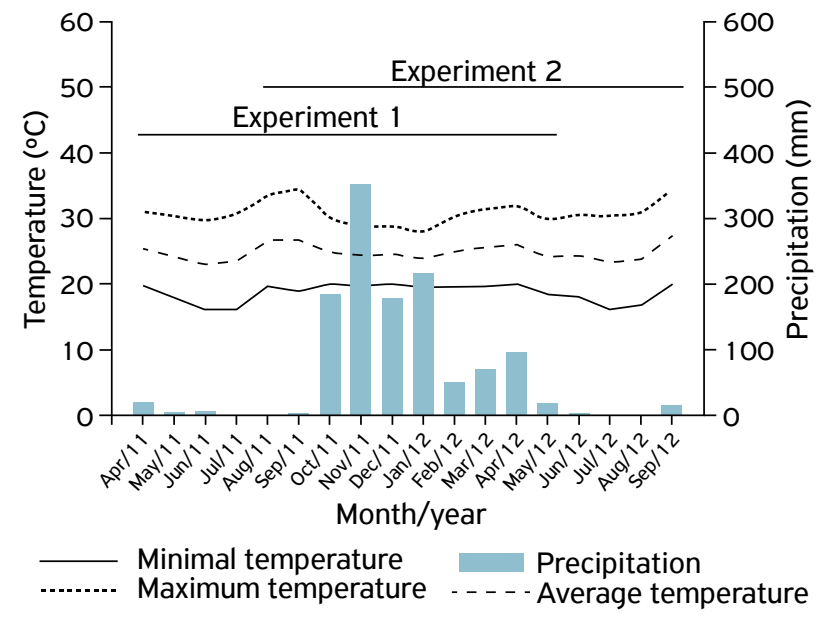

Figure 1. Minimal, average and maximum temperature (monthly average) and precipitation (accumulated month) during experimental period from April 2011 to September 2012. Goianésia, Goiás, Brazil. 
sub-samples collected to a depth from 0 to $25 \mathrm{~cm}$ and from 25 to $50 \mathrm{~cm}$ to determine soil chemical characteristics (Table 1). Soil correction was performed according to the results of soil chemical analysis. In the planting fertilization, $100 \mathrm{~kg} \cdot \mathrm{ha}^{-1}$ of $\mathrm{P}_{2} \mathrm{O}_{5}$ in the form of natural phosphate were applied. In the cover fertilization, 1,200 kg.ha ${ }^{-1}$ of the liquid fertilizer 05-00-12 + Boron $(0.3 \%)+$ Zinc $(0.3 \%)$ were used (ROSSETTO et al., 2008).

After the furrow, the planting was made manually. For termite control, insecticide fipronil $800 \mathrm{WG}\left(0.050 \mathrm{~kg} \cdot \mathrm{ha}^{-1}\right.$ p.c. $)$ was applied preventively. The control of weeds was carried out with application of herbicides in two phases of the experiments. The first application occurred after pre-emergence planting, with the hexazinone mixture $13.2 \%$ + diuron $46.8 \%(1.8 \mathrm{~kg}$. $\left.\mathrm{ha}^{-1}\right)$ and clomazone $80.0 \%\left(1.2 \mathrm{~kg} \cdot \mathrm{ha}^{-1}\right)$. The second application was performed after the inter-liner systematization, also in pre-emergence, with the mixture of isoxaflutol $75 \%$ $\left(0.12 \mathrm{~kg} \cdot \mathrm{ha}^{-1}\right)$ and tebuthiuron $80 \%\left(1.25 \mathrm{~kg} \cdot \mathrm{ha}^{-1}\right)$. For irrigation management, precipitation data $(\mathrm{mm})$ was obtained daily through a pluviometer installed at the experiment site. The water demand of the crop was determined, and $1,540 \mathrm{~mm}$ of water was applied throughout the crop cycle.

Analyses were carried out at laboratory of the Jalles Machado S/A power plant. For evaluation of infestation index, ten stems were randomly collected in the plot five days before harvest. Leaves, sheath and dry leaves were removed from these plants. At laboratory, the number of total internodes was counted, and stems were cut in the longitudinal direction of the sugarcane, counting the number of internodes that were injured due to the attack of the sugarcane borer. The infestation index was determined by the ratio of the number of internodes damaged by the total number of internodes. The percentage of internodes with red rot symptom (red color) was also estimated.

The ten stems were crushed and homogenized for extraction of cane juice by hydraulic press (TANIMOTO, 1964). The level of soluble solids (brix) and POL were determined according to the method of SCHNEIDER (1979). The parameters theoretically recoverable sugar (TRS) (kg of sugar per ton of sugarcane), fiber and purity were calculated according to the Sugarcane, Sugar and Alcohol Council of the state of São Paulo (CONSECANA, 2006). Reducing sugars (RS) were measured by the LANE \& EYNON'S volumetric method (1934). Plants were harvested at 396 days after planting, and yield per hectare was determined.

For data analysis, the Kolmogorov-Smirnov and Levene's tests were used to verify normality of residues and the homogeneity of variances, respectively. The data were submitted to analysis of variance (ANOVA) and the means of the treatments compared by the Scott-knott's test $(\mathrm{p}<0.05)$. A cluster analysis was performed using the Hierarquical cluster analysis (UPGMA) method based on the Euclidian distance to group cultivars by their level of resistance. Euclidean distance is recommended in cases in which the study variables are continuous. All statistical analyses were performed using the free software R, version 3.1.2 (R Development Core Team, 2017).

\section{RESULTS AND DISCUSSION}

At both experimental areas, all sugarcane cultivars were naturally infested by sugarcane borer, with average of infestation index varying from 1.2 to $8.7 \%$ of bored internodes, but no significant difference was observed between the treatments (Table 2). Some cultivars reached infestation levels considered high, once in Brazil the producers assume the level of damage of $3 \%$ of infestation

Table 2. Means $( \pm \mathrm{SE})$ of infestation index (II - \%) of Diatraea saccharalis and internodes with red rot (IRR - \%) in 16 sugarcane cultivars. Goianésia, GO, Brazil, 2012.

\begin{tabular}{|c|c|c|c|c|}
\hline \multirow{2}{*}{ Cultivar $^{1}$} & \multicolumn{2}{|c|}{ II (\%) } & \multicolumn{2}{|c|}{ IRR (\%) } \\
\hline & Exp. 1 & Exp. 2 & Exp. 1 & Exp. 2 \\
\hline СТC2 & $5.0 \pm 1.9$ & $2.9 \pm 1.5$ & $3.1 \pm 1.2 b$ & $1.7 \pm 1.0 \mathrm{~b}$ \\
\hline CTC4 & $1.4 \pm 0.8$ & $3.8 \pm 1.1$ & $0.9 \pm 0.6 c$ & $1.8 \pm 0.7 b$ \\
\hline СTC9 & $5.4 \pm 1.0$ & $7.1 \pm 1.0$ & $6.7 \pm 2.6 \mathrm{a}$ & $1.7 \pm 0.7 b$ \\
\hline CTC 11 & $3.5 \pm 1.5$ & $3.3 \pm 2.3$ & $0.3 \pm 0.2 c$ & $0.4 \pm 0.3 b$ \\
\hline CTC 15 & $2.8 \pm 1.1$ & $2.6 \pm 1.2$ & $1.4 \pm 1.4 \mathrm{c}$ & $1.1 \pm 0.8 b$ \\
\hline CTC 18 & $4.9 \pm 1.2$ & $6.8 \pm 2.5$ & $0.1 \pm 0.1 \mathrm{c}$ & $0.7 \pm 0.3 b$ \\
\hline IAC87-3396 & $2.2 \pm 1.6$ & $3.1 \pm 1.9$ & $0.2 \pm 0.2 c$ & $0.2 \pm 0.1 \mathrm{~b}$ \\
\hline IAC91-1099 & $3.5 \pm 0.7$ & $6.8 \pm 2.4$ & $1.0 \pm 0.7 \mathrm{c}$ & $0.8 \pm 0.5 b$ \\
\hline IACSP94-3046 & $4.8 \pm 1.8$ & $4.2 \pm 1.7$ & $1.9 \pm 1.8 \mathrm{c}$ & $0.6 \pm 0.6 \mathrm{~b}$ \\
\hline IACSP94-2094 & $1.2 \pm 0.6$ & $2.4 \pm 2.0$ & $0.0 \pm 0.0 \mathrm{c}$ & $0.0 \pm 0.0 \mathrm{~b}$ \\
\hline IACSP94-2101 & $1.6 \pm 0.6$ & $3.5 \pm 1.8$ & $0.2 \pm 0.2 c$ & $0.2 \pm 0.2 \mathrm{~b}$ \\
\hline IACSP95-5000 & $5.3 \pm 1.1$ & $8.7 \pm 1.5$ & $1.7 \pm 0.4 c$ & $1.7 \pm 0.6 b$ \\
\hline RB867515 & $4.0 \pm 1.3$ & $6.1 \pm 3.1$ & $0.4 \pm 0.4 c$ & $0.7 \pm 0.4 b$ \\
\hline RB92579 & $6.5 \pm 1.1$ & $5.6 \pm 1.4$ & $0.0 \pm 0.0 \mathrm{c}$ & $0.0 \pm 0.0 \mathrm{~b}$ \\
\hline RB966928 & $3.3 \pm 0.4$ & $3.9 \pm 2.1$ & $3.9 \pm 1.8 b$ & $4.2 \pm 1.5 \mathrm{a}$ \\
\hline SP86-0042 & $3.5 \pm 1.8$ & $1.8 \pm 1.4$ & $0.2 \pm 0.2 c$ & $1.0 \pm 0.8 b$ \\
\hline$F(15,63)$ & 1.65 & 1.24 & 2.89 & 2.60 \\
\hline$p$-value & 0.0977 & 0.2790 & 0.0030 & 0.0068 \\
\hline CV (\%) & 66.40 & 80.46 & 155.59 & 124.53 \\
\hline
\end{tabular}

'Means followed by equal letters, in the columns, do not differ by the Scott-Knott test ( $p>0.05$ ); CV: coefficient of variation; Exp.: experiment.

Table 1. Soil chemical characterization of the experimental area.

\begin{tabular}{|c|c|c|c|c|c|c|c|c|c|c|c|c|c|c|}
\hline Layer & OM & $P$ resin & Sulfur & K & $\mathrm{Ca}^{++}$ & $\mathrm{Mg}^{++}$ & $\mathrm{Al}^{++}$ & $\mathrm{H}^{+} \mathrm{Al}$ & $\mathrm{Ca} / \mathrm{Mg}$ & $\begin{array}{lll}T & \\
\end{array}$ & $\mathrm{pH}$ & m & v & Clay \\
\hline $\mathrm{cm}$ & g. kg $^{-1}$ & \multicolumn{2}{|c|}{ mg.kg-1 } & \multicolumn{7}{|c|}{$\mathrm{cmol}_{c} \cdot \mathrm{dm}^{-3}$} & $\mathrm{CaCl}_{2}$ & & $\%$ & \\
\hline $0-25$ & 20.12 & 0.80 & - & 0.19 & 0.92 & 0.32 & 0.58 & 2.80 & 2.90 & 4.20 & 4.50 & 29.29 & 25.95 & 45.54 \\
\hline $25-50$ & 15.22 & 0.80 & 2.00 & 0.07 & 0.20 & 0.08 & 0.64 & 2.00 & 2.50 & 2.30 & 4.30 & 68.09 & 9.53 & 43.22 \\
\hline
\end{tabular}

OM: organic matter; $\mathrm{P}$ resin: resin extractable phosphorus; $\mathrm{K}$ : potassium; $\mathrm{Ca}^{++}$: exchangeable calcium; $\mathrm{Mg}^{++}$: exchangeable magnesium; Al: exchangeable aluminum; $\mathrm{H}^{+} \mathrm{Al}$ : potential acidity; $\mathrm{T}$ : cation exchange capacity; $\mathrm{V}$ and $\mathrm{m}$ : bases and aluminum saturation. 
index, regardless the genotype used (MACEDO; LAVORENTI, 2004; MACEDO; MACEDO, 2004; PORTELA et al., 2011). In Louisiana, United States, it is common to consider the cultivar used to determine the damage level, e.g., for the cultivar L99-226, this level is $12 \%$, with only $0.30 \%$ of reduction on sugar ha ${ }^{-1}$ for each $1 \%$ of bored internodes (BEUZELIN et al., 2010; WHITE et al., 2008). Although no significant difference was observed between the cultivars for II, the cultivars CTC9, CTC2 and RB966928 at experiment 1 reached the higher percentages of internodes with red rot (IRR). At experiment 2, this fact repeated only for RB966928, with the highest percentage of IRR (Table 2). These results indicate higher susceptibility of these cultivars to fungi responsible to red rot. These pathogens contaminate the stems tissues, the important economically part of the sugarcane, damaging the quality of the cane juice and directly affecting the recovery of sugar in the mills. There is a complex network of signals involved in defensive responses that are still being elucidated in details (SATHYABHAMA et al., 2016). Studies carried out for identification of genes differentially expressed in sugarcane during the pathogenesis of Colletotrichum falcatum can generate materials that are more resistant to pathogens and more productive.

The TRS is one of the parameters of sugarcane payment system. In this study, at experiment 1, CTC4 and RB92579 showed significantly low TRS values, probably due the high percentages of reducing sugar, lower brix, purity and POL (Table 3). On the other hand, CTC9 obtained the best technological parameters, with the highest averages of brix, fiber, purity and POL (Table 3). Therefore, it is possible to notice that the cultivars with lower mean values of TRS are also those with lower values of technological quality, brix, purity and POL; and higher levels of RS, characteristics also observed by DINARDO-MIRANDA et al. (2012b, 2013). Sugarcane plants can response to injury and produce secondary compounds as phenols. For example, the production of phenols in response to spittlebug feeding (Hemiptera: Cercopidae) was responsible to changes in the sugar colour and reduction in sugar quality (MADALENO et al., 2008).

Still for experiment 1 , the higher yields (ton of sugar ha ${ }^{-1}$ ) were observed to CTC11, CTC15 and IAC91-1099, significantly different from the other ones. The CTC18 presented the worst performance, with the lowest average yield (Table 3). It should be remembered, however, that the II for CTC18 was high in the first experiment, with $4.9 \%$ of bored internodes, which may have resulted in the low average yield of this cultivar. There is a tendency of more modern cultivars be more susceptible to sugarcane borer than the older ones (DINARDO-MIRANDA et al., 2013). In studies involving five cultivars in the decade of 1980 , to each $1 \%$ of bored internodes by D. saccharalis, there was mean reduction of $0.8 \%$ in stems yield (PRECETTI et al., 1988). In 1990 decade, to each $1 \%$ of bored internodes the losses could reach to $1.5 \%$ in stems yield (ARRIGONI, 2002). Finally, in recent studies with ten cultivars of sugarcane, each $1 \%$ of bored internodes resulted in $2.9 \%$ reduction in stems yield (DINARDO-MIRANDA et al., 2013).

To experiment 2, it was possible to observe higher values of TRS for CTC15, IAC87-3396, IAC91-1099, IACSP94-3046, IACSP94-2094, IACSP94-2101, IACSP95-5000 and SP86-0042,

Table 3. Parameters of technological quality and yield of 16 sugarcane cultivars: experiment 1. Goianésia, GO, Brazil, 2012.

\begin{tabular}{|c|c|c|c|c|c|c|c|}
\hline \multirow{2}{*}{ Cultivar ${ }^{1}$} & \multicolumn{5}{|c|}{ Technological quality } & \multicolumn{2}{|c|}{ Yield } \\
\hline & ${ }^{\circ}$ Brix & Fiber & Purity & POL & RS & TRS & t cane ha-1 \\
\hline CTC2 & $16.3 \pm 0.3 c$ & $12.0 \pm 0.6 \mathrm{a}$ & $71.6 \pm 0.4 c$ & $11.7 \pm 0.3 b$ & $1.3 \pm 0.1 \mathrm{~b}$ & $124.3 \pm 2.0 \mathrm{~b}$ & $151.9 \pm 8.2 b$ \\
\hline CTC4 & $14.4 \pm 0.3 d$ & $10.2 \pm 0.2 b$ & $68.0 \pm 0.9 d$ & $9.8 \pm 0.3 c$ & $1.8 \pm 0.1 \mathrm{a}$ & $111.3 \pm 2.4 \mathrm{c}$ & $140.7 \pm 8.4 c$ \\
\hline СТС9 & $19.0 \pm 0.2 \mathrm{a}$ & $11.9 \pm 0.3 a$ & $77.3 \pm 0.6 \mathrm{a}$ & $14.7 \pm 0.2 \mathrm{a}$ & $0.7 \pm 0.1 \mathrm{c}$ & $147.7 \pm 1.7 \mathrm{a}$ & $157.5 \pm 4.7 b$ \\
\hline CTC11 & $17.2 \pm 0.3 c$ & $11.2 \pm 0.4 b$ & $74.7 \pm 0.3 b$ & $12.8 \pm 0.3 b$ & $1.0 \pm 0.1 \mathrm{~b}$ & $133.2 \pm 2.1 \mathrm{~b}$ & $162.6 \pm 6.4 \mathrm{a}$ \\
\hline СТC 15 & $17.6 \pm 0.2 b$ & $12.8 \pm 0.7 \mathrm{a}$ & $72.7 \pm 0.4 c$ & $12.8 \pm 0.2 b$ & $1.1 \pm 0.0 \mathrm{~b}$ & $133.3 \pm 1.3 b$ & $170.3 \pm 4.9 a$ \\
\hline СTC 18 & $16.2 \pm 0.2 c$ & $11.4 \pm 0.4 b$ & $73.1 \pm 0.7 c$ & $11.9 \pm 0.2 b$ & $1.2 \pm 0.1 \mathrm{~b}$ & $125.0 \pm 1.8 b$ & $108.6 \pm 3.3 \mathrm{e}$ \\
\hline IAC87-3396 & $16.8 \pm 0.3 c$ & $11.8 \pm 0.3 a$ & $72.6 \pm 0.5 c$ & $12.2 \pm 0.3 b$ & $1.2 \pm 0.1 \mathrm{~b}$ & $128.5 \pm 2.1 \mathrm{~b}$ & $154.8 \pm 5.2 b$ \\
\hline IAC91-1099 & $16.6 \pm 0.3 \mathrm{c}$ & $10.7 \pm 0.4 b$ & $74.0 \pm 0.6 b$ & $12.3 \pm 0.4 \mathrm{~b}$ & $1.2 \pm 0.1 \mathrm{~b}$ & $128.8 \pm 2.9 b$ & $168.6 \pm 2.6 \mathrm{a}$ \\
\hline IACSP94-3046 & $16.6 \pm 0.4 c$ & $10.3 \pm 0.3 b$ & $74.5 \pm 0.7 b$ & $12.4 \pm 0.4 b$ & $1.2 \pm 0.1 \mathrm{~b}$ & $129.7 \pm 2.7 b$ & $137.6 \pm 3.5 c$ \\
\hline IACSP94-2094 & $17.3 \pm 0.6 \mathrm{c}$ & $11.9 \pm 0.4 \mathrm{a}$ & $74.2 \pm 1.4 b$ & $12.8 \pm 0.7 b$ & $1.0 \pm 0.1 \mathrm{~b}$ & $132.9 \pm 5.7 b$ & $130.8 \pm 5.7 d$ \\
\hline IACSP94-2101 & $16.1 \pm 0.5 c$ & $10.9 \pm 0.3 b$ & $72.5 \pm 0.8 c$ & $11.7 \pm 0.5 b$ & $1.3 \pm 0.1 \mathrm{~b}$ & $124.6 \pm 3.8 b$ & $130.0 \pm 1.8 \mathrm{~d}$ \\
\hline IACSP95-5000 & $17.2 \pm 0.4 \mathrm{c}$ & $11.2 \pm 0.6 \mathrm{~b}$ & $73.7 \pm 0.6 b$ & $12.7 \pm 0.4 b$ & $1.1 \pm 0.1 \mathrm{~b}$ & $132.3 \pm 2.6 b$ & $144.6 \pm 2.4 c$ \\
\hline RB867515 & $15.9 \pm 0.4 c$ & $11.0 \pm 0.5 b$ & $71.6 \pm 0.7 c$ & $11.4 \pm 0.3 b$ & $1.4 \pm 0.1 \mathrm{~b}$ & $122.5 \pm 2.3 b$ & $155.0 \pm 2.5 b$ \\
\hline RB92579 & $14.0 \pm 0.4 \mathrm{~d}$ & $11.0 \pm 0.9 \mathrm{~b}$ & $66.9 \pm 1.6 \mathrm{~d}$ & $9.4 \pm 0.5 c$ & $1.8 \pm 0.1 \mathrm{a}$ & $107.3 \pm 3.4 c$ & $156.9 \pm 3.7 b$ \\
\hline RB966928 & $16.8 \pm 0.6 c$ & $11.7 \pm 0.8 \mathrm{a}$ & $73.5 \pm 1.0 \mathrm{c}$ & $12.3 \pm 0.6 b$ & $1.1 \pm 0.2 b$ & $128.9 \pm 4.4 b$ & $130.3 \pm 2.6 \mathrm{~d}$ \\
\hline SP86-0042 & $16.6 \pm 0.1 \mathrm{c}$ & $10.6 \pm 0.4 b$ & $74.0 \pm 0.4 b$ & $12.3 \pm 0.1 \mathrm{~b}$ & $1.2 \pm 0.0 \mathrm{~b}$ & $129.1 \pm 0.7 b$ & $156.9 \pm 2.2 b$ \\
\hline$F(15,63)$ & 9.01 & 2.35 & 10.03 & 9.85 & 8.63 & 9.92 & 16.38 \\
\hline $\mathrm{p}$-value & $<0.0001$ & 0.0139 & $<0.0001$ & $<0.0001$ & $<0.0001$ & $<0.0001$ & $<0.0001$ \\
\hline CV (\%) & 4.64 & 8.24 & 2.16 & 6.38 & 15.48 & 4.56 & 5.58 \\
\hline
\end{tabular}

POL: apparent sucrose content; RS: reducing sugars; TRS: theoretically recoverable sugar (kg of sugar per ton of cane); ${ }^{1}$ means followed by equal letters, in the columns, do not differ by the Scott-Knott test ( $p>0.05)$; CV: coefficient of variation. 
due the higher values on brix contents, purity and POL in the sugarcane (Table 4). Only CTC4, CTC18, IACSP94-2101 and RB966928 did not obtain good yields in this experiment, with significantly lower averages than the other cultivars (Table 4). This result corroborates the observed in experiment 1 (Table 3). In this study, cultivars with negative effect in the technological quality did not present lower averages of yield. Some pests as nematodes can significantly reduce the agricultural yield, but did not interfere in sugarcane quality, as raw material for the industry (DINARDO-MIRANDA et al., 2002).
According to the cluster analysis, based on data from II, IRR, technological quality and yield of sugarcane, it was possible to observe differences between each group of sugarcane cultivars according to the degree of similarity. At experiment 1, IAC91-1099 and CTC15 were similar due the lowest Euclidian distance, followed by CTC11, RB867515, CTC2, SP86-0042, IAC87-3396, CTC9, IACSP95-5000, IACSP94-3046, RB966928, IACSP94-2094 and IACSP94-2101, forming the group with higher degree of resistance to $D$. saccharalis (Fig. 2). CTC4 and RB92579 formed the second group with

Table 4. Parameters of technological quality and yield of 16 sugarcane cultivars: experiment 2. Goianésia, GO, Brazil, 2012.

\begin{tabular}{|c|c|c|c|c|c|c|c|}
\hline \multirow{2}{*}{ Cultivar ${ }^{1}$} & \multicolumn{5}{|c|}{ Technological quality } & \multicolumn{2}{|c|}{ Yield } \\
\hline & Brix & Fiber & Purity & POL & RS & TRS & t cane ha ${ }^{-1}$ \\
\hline CTC2 & $22.1 \pm 0.1 \mathrm{a}$ & $13.2 \pm 0.3 \mathrm{a}$ & $79.5 \pm 0.5 b$ & $17.6 \pm 0.1 \mathrm{~b}$ & $0.4 \pm 0.0 \mathrm{~b}$ & $172.6 \pm 1.3 b$ & $128.6 \pm 7.7 \mathrm{a}$ \\
\hline CTC4 & $21.2 \pm 0.6 b$ & $11.0 \pm 0.5 b$ & $79.4 \pm 0.9 b$ & $16.9 \pm 0.7 b$ & $0.6 \pm 0.1 \mathrm{a}$ & $168.0 \pm 5.2 b$ & $90.6 \pm 6.6 b$ \\
\hline СТC9 & $21.7 \pm 0.5 b$ & $11.9 \pm 0.7 b$ & $80.8 \pm 1.0$ a & $17.5 \pm 0.6 \mathrm{~b}$ & $0.4 \pm 0.1 \mathrm{~b}$ & $172.3 \pm 4.6 b$ & $106.3 \pm 6.3 \mathrm{a}$ \\
\hline CTC 11 & $21.8 \pm 0.5 b$ & $11.5 \pm 0.3 b$ & $80.1 \pm 0.4 b$ & $17.4 \pm 0.5 b$ & $0.5 \pm 0.1 \mathrm{a}$ & $172.2 \pm 4.2 b$ & $118.6 \pm 5.4 \mathrm{a}$ \\
\hline СТC 15 & $23.0 \pm 0.2 \mathrm{a}$ & $13.6 \pm 0.0 \mathrm{a}$ & $78.9 \pm 0.4 b$ & $18.1 \pm 0.2 \mathrm{a}$ & $0.4 \pm 0.0 \mathrm{~b}$ & $178.1 \pm 2.0 \mathrm{a}$ & $118.1 \pm 10.0 \mathrm{a}$ \\
\hline СTC 18 & $21.5 \pm 0.3 b$ & $12.1 \pm 0.4 \mathrm{~b}$ & $79.2 \pm 0.7 \mathrm{~b}$ & $17.0 \pm 0.3 b$ & $0.5 \pm 0.0 \mathrm{a}$ & $168.6 \pm 2.3 b$ & $85.3 \pm 7.4 b$ \\
\hline IAC87-3396 & $22.5 \pm 0.2 \mathrm{a}$ & $13.4 \pm 0.6 \mathrm{a}$ & $79.8 \pm 0.5 b$ & $17.9 \pm 0.1 \mathrm{a}$ & $0.3 \pm 0.0 \mathrm{~b}$ & $175.8 \pm 0.7 \mathrm{a}$ & $110.8 \pm 3.8 \mathrm{a}$ \\
\hline IAC91-1099 & $22.1 \pm 0.3 \mathrm{a}$ & $11.8 \pm 0.4 b$ & $80.8 \pm 0.2 \mathrm{a}$ & $17.8 \pm 0.2 \mathrm{a}$ & $0.4 \pm 0.0 \mathrm{~b}$ & $175.1 \pm 2.0 \mathrm{a}$ & $122.2 \pm 4.8 \mathrm{a}$ \\
\hline IACSP94-3046 & $22.6 \pm 0.3 a$ & $11.3 \pm 0.4 \mathrm{~b}$ & $81.9 \pm 0.2 \mathrm{a}$ & $18.5 \pm 0.3 a$ & $0.3 \pm 0.1 \mathrm{~b}$ & $181.4 \pm 2.4 \mathrm{a}$ & $124.9 \pm 3.8 \mathrm{a}$ \\
\hline IACSP94-2094 & $23.0 \pm 0.1 \mathrm{a}$ & $12.1 \pm 0.3 b$ & $81.7 \pm 0.2 \mathrm{a}$ & $18.8 \pm 0.1 \mathrm{a}$ & $0.3 \pm 0.0 \mathrm{~b}$ & $183.2 \pm 1.0 \mathrm{a}$ & $107.1 \pm 4.7 \mathrm{a}$ \\
\hline IACSP94-2101 & $22.2 \pm 0.4 a$ & $11.6 \pm 0.2 \mathrm{~b}$ & $80.5 \pm 0.7 \mathrm{a}$ & $17.9 \pm 0.5 a$ & $0.4 \pm 0.1 \mathrm{~b}$ & $176.0 \pm 3.9 \mathrm{a}$ & $95.1 \pm 4.2 \mathrm{~b}$ \\
\hline IACSP95-5000 & $22.3 \pm 0.3 a$ & $11.7 \pm 0.4 \mathrm{~b}$ & $80.8 \pm 0.7 \mathrm{a}$ & $18.0 \pm 0.3 a$ & $0.4 \pm 0.1 \mathrm{~b}$ & $177.2 \pm 2.6 \mathrm{a}$ & $111.1 \pm 3.5 \mathrm{a}$ \\
\hline RB867515 & $22.1 \pm 0.3 \mathrm{a}$ & $12.4 \pm 0.3 \mathrm{a}$ & $79.2 \pm 0.3 b$ & $17.5 \pm 0.3 b$ & $0.5 \pm 0.1 \mathrm{a}$ & $172.9 \pm 2.6 b$ & $116.1 \pm 3.2 \mathrm{a}$ \\
\hline RB92579 & $21.2 \pm 0.6 b$ & $11.1 \pm 0.5 b$ & $79.0 \pm 1.2 \mathrm{~b}$ & $16.8 \pm 0.7 b$ & $0.6 \pm 0.1 \mathrm{a}$ & $167.3 \pm 5.5 b$ & $114.4 \pm 6.4 \mathrm{a}$ \\
\hline RB966928 & $21.3 \pm 0.4 b$ & $12.4 \pm 0.2 \mathrm{a}$ & $78.8 \pm 0.5 b$ & $16.8 \pm 0.4 b$ & $0.5 \pm 0.1 \mathrm{a}$ & $166.2 \pm 3.4 b$ & $99.9 \pm 2.5 b$ \\
\hline SP86-0042 & $22.5 \pm 0.3 a$ & $12.8 \pm 0.6 \mathrm{a}$ & $79.7 \pm 0.8 \mathrm{~b}$ & $17.9 \pm 0.4 \mathrm{a}$ & $0.4 \pm 0.0 \mathrm{~b}$ & $176.0 \pm 3.5 \mathrm{a}$ & $126.3 \pm 2.5 \mathrm{a}$ \\
\hline$F(15,63)$ & 2.45 & 3.84 & 2.45 & 2.35 & 2.57 & 2.32 & 5.53 \\
\hline$p$-value & 0.0104 & 0.0002 & 0.0105 & 0.0137 & 0.0075 & 0.015 & $<0.0001$ \\
\hline CV(\%) & 3.33 & 6.61 & 1.56 & 4.37 & 29.70 & 3.69 & 9.89 \\
\hline
\end{tabular}

POL: apparent sucrose content; RS: reducing sugars; TRS: theoretically recoverable sugar (kg of sugar per ton of cane); ${ }^{1}$ means followed by equal letters, in the columns, do not differ by the Scott-Knott test ( $p>0.05)$; CV: coefficient of variation.

Experiment 1

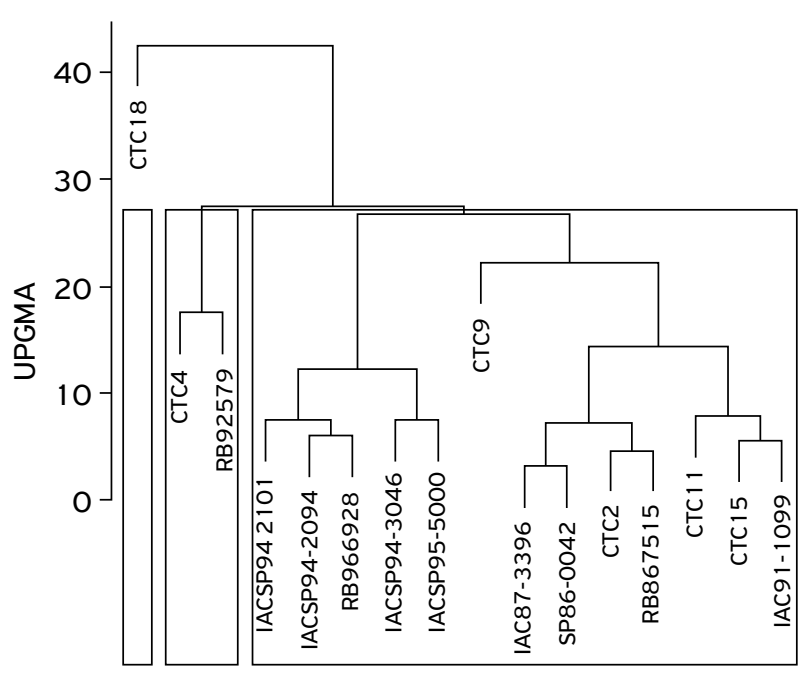

Experiment 2

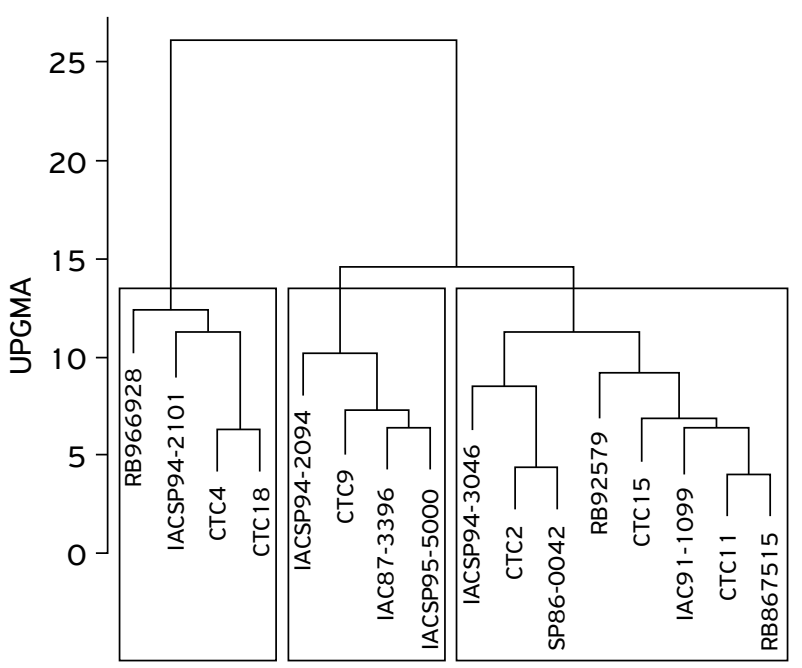

Figure 2. Dendrogram resulting from the grouping analyses, using the hierarchical cluster analysis (UPGMA) method, based on the Euclidian distance, from the parameters of technological quality, yield and damage of Diatraea saccharalis on 16 sugarcane cultivars. 
intermediate varieties; and the cultivar CTC18 formed the last group, with the higher Euclidian distance and distinct from the other formed groups. At experiment 2, RB867515, CTC11, IAC91-1099, CTC15, RB92579, SP86-0042, CTC2 and IACSP94-3046 formed the first group, with higher degree of resistance; IACSP95-5000, IAC87-3396, CTC9 and IACSP94-2094 formed the second group of intermediate cultivars; and CTC18, CTC4, IACSP94-2101 and RB966928 formed the last group. The cultivars CTC18, CTC4, RB92579, IACSP94-2101 and RB966928 were little similar with the other cultivars and presented higher susceptibility to $D$. saccharalis.

Values of cophenetic correlation lower than 0.7 indicate the inadequacy of the grouping method, evidencing the existence of a regular fit between the dissimilarity matrix and the dendrogram obtained in the experiments (ROHLF, 1970; SOUZA et al., 2013). In this study, the coefficients of cophenetic correlation (r) were 0.79 and 0.78 for experiments 1 and 2 , respectively. Therefore, the use of the analysis of means comparison, in conjunct with the grouping techniques, was efficient in the discrimination of sugarcane cultivars regarding yield, technological quality and damages of $D$. saccharalis.

In summary, it is important that each new cultivar released for trade be carefully evaluated to provide advanced information on resistance to sugarcane borer. Specific information on resistant cultivars to $D$. saccharalis may allow the producers to implement integrated pest management and contribute to the environment through the reduction of the use of insecticides required for the control of this insect in the sugarcane crop.

\section{CONCLUSION}

The cultivars with the worst performances of technological quality and yield were CTC18, CTC4, RB92579, RB966928 and IACSP94-2101, due to the reduction in the contents of brix, POL and purity; and increase of the reducing sugars and, consequently, lower TRS and the highest percentages of IRR. The cultivars RB867515, CTC11, IAC91-1099, CTC15, SP86-0042, CTC2 and IACSP94-3046 presented the highest degrees of resistance to $D$. saccharalis and, therefore, produced the best results of technological quality and yield.

\section{ACKNOWLEDGMENTS}

To Jalles Machado S/A power plant, for the facilities provision for the execution of the experiments and technical support in the field works.

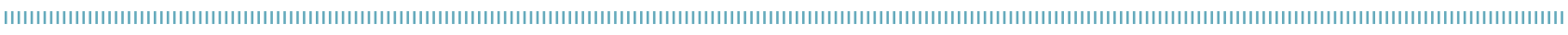
REFERENCES

ALVARES, C.A.; STAPE, J.L.; SENTELHAS, P.C.; GONÇALVES, J.L.D.M.; SPAROVEK, G. Köppen's climate classification map for Brazil. Meteorologische Zeitschrift, v.22, n.6, p.711-728, 2013.

ARRIGONI, E.B. Broca da cana de açúcar: Importância econômica e situação atual. In: ARRIGONI, E.B.; DINARDO MIRANDA, L.L.; ROSSETO, R. (Eds.). Pragas da cana de açúcar: Importância econômica e enfoques atuais. Piracicaba: STAB/IAC/CTC, 2002.

BEUZELIN, J.M.; AKBAR, W.; MÉSZÁROS, A.; REAY JONES, F.P.F.; REAGAN, T.E. Field assessment of novaluron for sugarcane borer, Diatraea saccharalis (F.) (Lepidoptera: Crambidae), management in Louisiana sugarcane. Crop Protection, v.29, n. 10, p.1 168-1 176, 2010.

CONAB. Acompanhamento da safra brasileira de Cana de açúcar. Companhia Nacional de Abastecimento, 2015. Available from: <http://www.conab.gov.br/conteudos.php?a=1253\&>. Accessed on: Dec 152016.

CONSECANA. Manual de instruções. 5. ed. Piracicaba: Conselho dos Produtores de Cana de Açúcar Açúcar e Álcool do Estado de São Paulo, 2006.

DINARDO MIRANDA, L.L. Pragas. In: DINARDO MIRANDA, L.L.; VASCONCELOS, A.C.M.; LANDELL, M.G.A. (Eds.). Cana de açúcar. Campinas: Instituto Agronômico, 2008. p.349-404.
DINARDO MIRANDA, L.L.; ANTÔNIO, I.; COSTA, V.P.; FRACASSO, J.V. Resistance of sugarcane cultivars to Diatraea saccharalis. Pesquisa Agropecuaria Brasileira, v.47, n. 1, p.1-7, 2012 a.

DINARDO MIRANDA, L.L.; FRACASSO, J.V.; ANJOS, I.A.; GARCIA, J.; COSTA, V.P. Influêcia da infestação de Diatraea saccharalis (Fabr.) sobre parâmetros tecnológicos da cana de açúcar. Bragantia, v.71, n.3, p.342-345, 2012 b.

DINARDO MIRANDA, L.L.; FRACASSO, J.V.; COSTA, V.P. Da; ANJOS, I.A. Dos; LOPES, D.O.P. Reação de cultivares de cana de açúcar à broca do colmo. Bragantia, v.72, n. 1, p.29-34, 2013.

DINARDO MIRANDA, L.L.; FRACASSO, J.V.; PERECIN, D. Variabilidade espacial de populações de Diatraea saccharalis em canaviais e sugestão de método de amostragem. Bragantia, v.70, n.3, p.577-585, 2011.

DINARDO MIRANDA, L.L; GACIA, V.; PARAZZI, V.J. Efeito de inseticidas no controle de Mahanarva fimbriolata (Stål) (Hemiptera: Cercopidae) e de nematóides fitoparasitos na qualidade tecnológica ena produtividade da cana de açúcar. Neotropical Entomology, v.3 1, n.4, p.609-614, 2002.

FAO. FAO statistical yearbook 2015. Available from: <http:// www.fao.org/docrep/018/i3 107e/i3107e00.htm>. Accessed on: Jun 252014 . 
LANE, J.H.; EYNON, L. Determination of reducing sugars by Fehling's solution with methylene blue indicator. London: Normam Rodge, 1934.

LARA, F.M. Princípios de resistência de plantas a insetos. São Paulo: Ícone, 1991.

MACEDO, N.; LAVORENTI, N. Novo método de amostragem de intensidade de infestação da broca da cana de açúcar (Diatraea saccharalis). STAB, v.22, n.3, p.32-41, 2004.

MACEDO, N.; MACEDO, D. As pragas de maior incidência nos canaviais e seus controles. Visão Agrícola, v. 1, n. 1, p.38-46, 2004.

MADALENO, L.L.; RAVANELI, G.C.; PRESOTTI, L.E.; MUTTON, M.A.; FERNANDES, O.A.; MUTTON, M.J.R. Influence of Mahanarva fimbriolata (Stål) (Hemiptera: Cercopidae) injury on the quality of cane juice. Neotropical Entomology, v.37, n. 1, p.68-73, 2008.

PORTELA, G.LF;:PÁDUA, LE.M.; BRANCO, R.T.P.C.;BARBOSA, O.A.; SILVA, P.R.R. Infestation of Diatraea spp. in different varieties of sugar cane in the city of União PI. Revista Caatinga, v.24, n. 1, p.149-152, 2011.

PRECETTI, A.A.C.M.; TERÁN, F.O.; SANCHEZ, A.G. Alterações nas características tecnológicas de algumas cultivares de cana de açúcar, devidas ao dano da broca Diatraea saccharalis. Boletim Técnico Copersucar, v.40, p.3-8, 1988.

R DEVELOPMENT CORE TEAM. R: A language and environment for statistical computingViennaR Foundation for Statistical Computing, 2017. Available from: <http://wwwr projectorg/>. Accessed on: Fev 152018.

ROHLF, F.J. Adaptive hierarchical clustering schemes. Systematic Zoology, v.18, n.1, p.58-82, 1970.
ROSSETTO, R.; DIAS, F.L.F.; VITTI, A.C. Problemas nutricionais dos solos nas novas fronteiras canavieiras. Idea News, v.8, n.94, p.78-90, 2008.

SANTOS, H.G.; JACOMINE, P.K.T.; ANJOS, L.H.C.; OLIVEIRA, V.Á.; LUMBRERAS, J.F.; COELHO, M.R.; ALMEIDA, J.A.; CUNHA, T.J.F. OLIVEIRA, J.B. Sistema brasileiro de classificação de solos. 3. ed. Brasília: Embrapa, 2013.

SATHYABHAMA, M.; VISWANATHAN, R.; MALATHI, P.; SUNDAR, A.R. Identification of differentially expressed genes in sugarcane during pathogenesis of Colletotrichum falcatum by suppression subtractive hybridization (SSH). Sugar Tech, v.18, n.2, p.176-183, 2016.

SCHNEIDER, F. Sugar analysis methods. Peterborough: ICUMSA, 1979.

SOUZA, J.R.; BOIÇA JÚNIOR, A.L.; PERECIN, D.; CARGNELUTTI FILHO, A.; COSTA, J.T. Divergência genética de cultivares de cana de açúcar quanto à resistência a Diatraea saccharalis. Semina: Ciências Agrárias, v.34, n.6, Supl 1, p.3367, 2013.

TANIMOTO, T. The press method of cane analysis. Hawaiian Planter's Record, v.51, p.133-150, 1964.

VISWANATHAN, R.; RAMESH SUNDAR, A.; MALATHI, P.; RAHUL, P.R.; GANESH KUMAR, V.; BANUMATHY, R.; PRATHIMA, P.T.; RAVEENDRAN, M.; KUMAR, K.K.; BALASUBRAMANIAN, P. Interaction between sugarcane and Colletotrichum falcatum causing red rot: Understanding disease resistance at transcription level. Sugar Tech, v. 11 , n. 1, p.44-50, 2009.

WHITE, W.H.; VIATOR, R.P.; DUFRENE, E.O.; DALLEY, C.D.; RICHARD, E.P.; TEW, T.L. Re evaluation of sugarcane borer (Lepidoptera: Crambidae) bioeconomics in Louisiana. Crop Protection, v.27, p. 1256-1261, 2008. 